\title{
Synthesized Li2B407: Mg,Cu nanoparticles: a suitable thermoluminescence dosimeter for detection of high doses of gamma rays
}

Mohsen Mehrabi ( $\square$ m.mehrabi@pgu.ac.ir)

Persian Gulf University https://orcid.org/0000-0002-5074-461X

Mostafa Zahedifar

University of Kashan

soheila hasanloo

Arak University

hossein Nikmanesh

Persian Gulf University

Rouhollah Gheisari

Persian Gulf University

yangtao li

ji lin jian zhu gong cheng xue yuan: Jilin Jianzhu University

\section{Research Article}

Keywords: Synthesized Li2B407, lithium, gamma rays

Posted Date: August 24th, 2021

DOI: https://doi.org/10.21203/rs.3.rs-841528/v1

License: () (1) This work is licensed under a Creative Commons Attribution 4.0 International License.

Read Full License 


\title{
Synthesized $\mathrm{Li}_{2} \mathrm{~B}_{4} \mathrm{O}_{7}$ : $\mathrm{Mg}, \mathrm{Cu}$ nanoparticles: a suitable thermoluminescence dosimeter for detection of high doses of gamma rays
}

\author{
Mohsen. Mehrabi ${ }^{\text {a.* }}$, Mostafa. Zahedifar ${ }^{\text {b,c }}$, Soheila. Hasanloo ${ }^{\text {d }}$ Hossein Nikmanesh ${ }^{\mathrm{a}}$, \\ Rouhollah Gheisari ${ }^{\mathrm{a}, \mathrm{e}}$, Yongtao $\mathrm{Li}^{\mathrm{f}}$ \\ ${ }^{a}$ Physics Department, Persian Gulf University, Bushehr, Iran, P. O. Box: 7516913817 \\ ${ }^{\mathrm{b}}$ Physics Department, University of Kashan, Kashan, Iran \\ ${ }^{c}$ Institute of Nanoscience and Nanotechnology, University of Kashan, Kashan, Iran \\ ${ }^{d}$ Physics Department, Faculty of science, Arak University, Arak, Iran. \\ ${ }^{e}$ Nuclear Energy Research Center, Persian Gulf University, Bushehr, Iran \\ ${ }_{\mathrm{f}}^{\mathrm{f}}$ School of Materials Science and Engineering, Ji Lin Jian Zhu University, Changchun, 130018, China
}

\begin{abstract}
:
Lithium tetraborate nanoparticles co-doped with various percentages of $\mathrm{Cu}$ and $\mathrm{Mg}$ impurities were synthesized through the combustion process. Scanning electron microscopy images along with X-Ray diffraction pattern confirmed the shape and structure of the products. The Williamson-Hall equation was used to measure the size of nanoparticles that resulted in approximately $47 \mathrm{~nm}$ for the crystallite size. The optical band gap of about $3.7 \mathrm{eV}$ was obtained for the nanostructures from the UV-visible spectrum. Furthermore, the thermoluminescence features the samples under gamma irradiation were studied at ambient conditions. The highest thermoluminescence sensitivity achieved at $0.02 \% \mathrm{wt} \mathrm{Cu}$ and $0.5 \% \mathrm{wt} \mathrm{Mg}$ impurities simultaneously. The results show that the codoped nanoparticles have a linear dose response up to an administrated dose of $30 \mathrm{kGy}$ and about $10 \%$ of the thermoluminescence signal fades after 30 days of storage at room temperature.
\end{abstract}

Keywords: Combustion Method, Nanoparticle, Lithium tetraborate, Thermoluminescence, Band gap, Dosimetry.

*Address for correspondence: Physics Department, Persian Gulf University, Bushehr, Iran. P. O. Box: 7516913817; Email: m.mehrabi@pgu.ac.ir

Tel: +9877-31223389

Fax: +9877-33441494 


\section{INTRODUCTION}

Ideal thermoluminescence (TL) materials should possess specific features, including linear dose-response, accuracy, near tissue equivalence, high sensitivity, excellent stability, well-defined TL glow curve, and a simple annealing process. So far, many dosimetric materials are employed in radiation dosimetry, and a lot of new compounds have been synthesized, but none of them matches all the desired characteristics of an ideal detector. Therefore, attempts have always been made to either prepare new TL dosimeters (TLDs) with better properties or simply improve the already existing dosimetric materials by varying the concentration of impurities or co-doping the phosphor with other elements or doping new impurities in new structures [1]. the glow peaks in the TL glow curves are explained by special parameters such as Kinetic parameters and the number of trapped electrons $[2,3]$. So far, different materials have been synthesized to study their TL response in different ionizing radiation fields [4]. Amongst different TL phosphors, lithium borates due to their tissue equivalence are of great interest in TL dosimetry. In this regard, lithium tetraborate $\left(\mathrm{Li}_{2} \mathrm{~B}_{4} \mathrm{O}_{7}\right)$ crystal is widely used for radiation measurement, especially radiation therapy and personal dosimeters because its effective atomic number $(\sim 7.3)$ is very close to the soft tissue of the body $(\sim 7.4)$ [5]. Indeed, the lithium borate dosimeters are superior to many which is used as a TL dosimeter in terms of tissue equivalence [5-9]. Besides, most of the borates are relatively stable chemical compounds and easy to handle. Furthermore, by adding elements as activators, the resultant materials will have high sensitivity, linear dose response and good stability when stored in environmental conditions. Therefore, deficiencies such as fading, low sensitivity and poor humidity are not seen in them. In addition, lithium borate crystals doped with different elements have the ability to detect neutrons due to the presence of Li and B, both of which have large neutron absorption capacities. During the past decades, a great deal of research has been focused on the synthesis and study the physical properties of borate compounds $[10,11]$. Generally, $\mathrm{Li}_{2} \mathrm{~B}_{4} \mathrm{O}_{7}(\mathrm{LTB})$ as a borate compound is used in the dosimetric application but it does not comply with all the requirements so studies are still being continued to improve its properties [12-18]. Over the past few years, attempts have been devoted to TL properties of nanomaterials because of their exceptional TL response compared with their bulk counterparts [19-36]. The basic problem with the conventional TL materials is saturation of trapping states at high absorbed doses, which causes the TL response to become sub-linear in high radiation exposure. A general feature of nanostructures is that they exhibit linear dose response at higher exposures, where the known micro-scaled TL materials saturate [37]. LTB is one of the important nano-crystals that is produced in different shapes and sizes to improve its optical properties in a variety of techniques [37-38]. However, the TL properties of LTB: Cu-Mg nanoparticles (NPs) have not been reported so far. This work deals with the synthesis procedure of LTB-NPs co- 
doped with different percentage of $\mathrm{Cu}$ and $\mathrm{Mg}$ via the combustion method. X-Ray diffraction patterns (XRD) along with scattering electron microscopy (SEM) were used to determine the structure, shape and size of NPs. In the following, the optical properties of LTB-NPs including the UV-visible spectrum as a tool to estimate the optical band gap as well as TL dosimetry features under gamma irradiation for personal dosimetry application are presented.

\section{MATERIALS AND METHODS}

LTB-NPs co-doped by $\mathrm{Cu}$ and Mg impurities were synthesized by the solid-state reaction route. All materials used in this work were produced from Merck Corporation with high purity. Firstly, $0.696 \mathrm{~g}$ of Lithium nitrate, $0.925 \mathrm{~g}$ of Boric acid, $4.082 \mathrm{~g}$ of Ammonium nitrate and $3.062 \mathrm{~g}$ of Urea were mixed and pulverized for $5 \mathrm{~min}$. Then, the mixture was placed in a furnace at different temperature $\left(380^{\circ} \mathrm{C}, 480^{\circ} \mathrm{C}, 580^{\circ} \mathrm{C}\right)$ for one hour. Subsequently, productions were crushed for $10 \mathrm{~min}$. Finally, the nano-powder was annealed at $450{ }^{\circ} \mathrm{C}$ for 10 minutes in a crucible and was quenched by taking the crucible out of the furnace and placing it on a metal block. Various amounts of Copper nitrate and Magnesium nitrate were added to the starting mixture for producing LTBNPs doped with $\mathrm{Cu}$ and $\mathrm{Mg}$.

The structure of the powders was specified via $\mathrm{XRD}$ at room temperature by using $\mathrm{Cu}$-target $\left(\mathrm{Cu}-\mathrm{K}_{\alpha}\right.$ line, $\lambda=1.54056 \AA$ ) with Rigaku D-maxc III diffractometer. The shape and morphology were specified via SEM (Model KYKY-EM3200). The UV-visible absorption spectrum was recorded by using Shimadzu UV1700 spectrometer. All the irradiations were carried out using ${ }^{60} \mathrm{Co}$ source at the secondary standard Dosimetry Laboratory (SSDL) at Karaj-Iran. TL glow curves were recorded at a TLD reader model Harshaw 4500 by the contact heating with the heating rate of $1 \mathrm{~K} / \mathrm{sec}$.

\section{RESULTS AND DISCUSSION:}

The SEM images of the samples synthesized by combustion method at 380,480 and $580^{\circ} \mathrm{C}$ are shown in figure $1 \mathrm{a}, \mathrm{b}$ and $\mathrm{c}$ respectively.

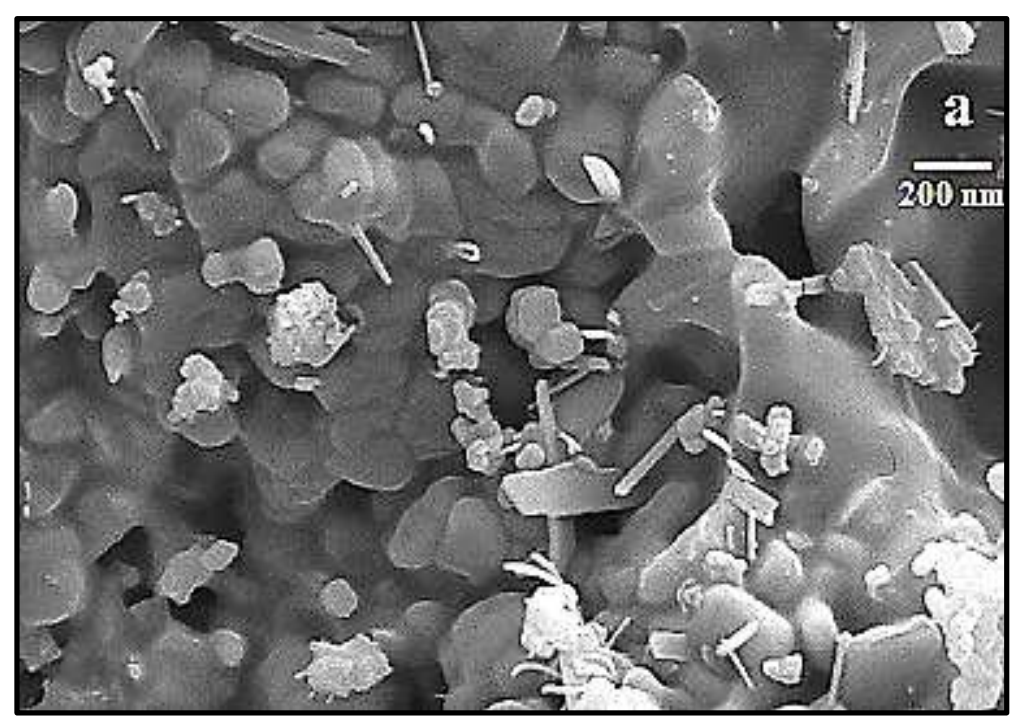




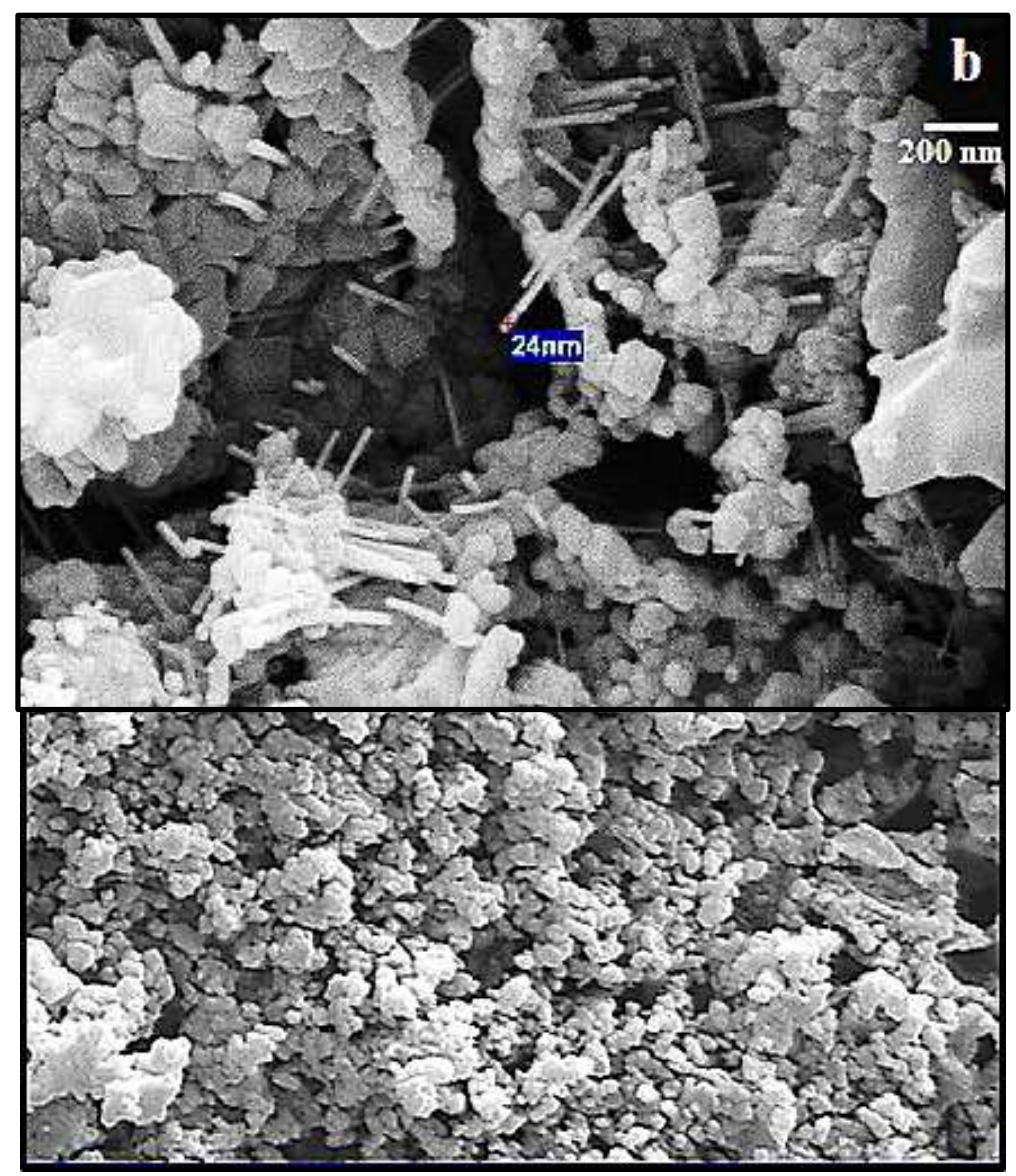

Fig 1. SEM images of LTB: $\mathrm{Cu}, \mathrm{Mg}(0.02 \mathrm{wt} \% \mathrm{Cu}$ and $0.5 \mathrm{wt} \% \mathrm{Mg})$ synthesized by combustion method at different temperatures of a) $\left.\left.380^{\circ} \mathrm{C} \mathrm{b}\right) 480^{\circ} \mathrm{C} \mathrm{c}\right) 580^{\circ} \mathrm{C}$.

As is observed, at $380^{\circ} \mathrm{C}$, the bulk material is clinging and with increasing the temperature to $480^{\circ} \mathrm{C}$ the particle size become smaller and the composition of spherical and rod nanoparticles are formed. At the temperature of $580^{\circ} \mathrm{C}$ nanoparticles are produced which refers to the process of burning and complete composition of raw materials in the reaction. The structure of the produced LTB was investigated by XRD patterns, which is shown in figure 2. 


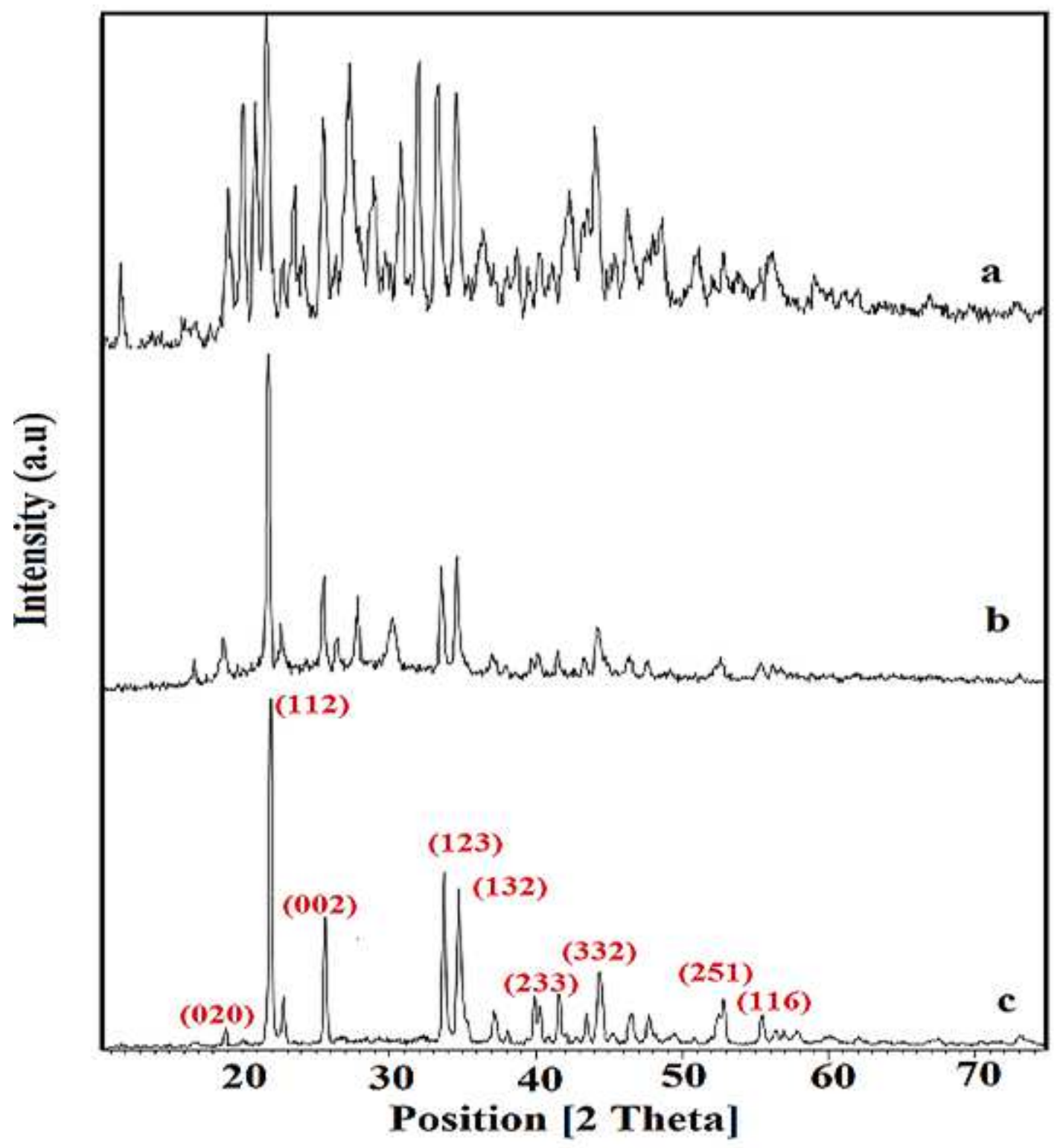

Fig. 2. XRD patterns of LTB: $\mathrm{Cu}, \mathrm{Mg}(0.02 \mathrm{wt} \% \mathrm{Cu}$ and $0.5 \mathrm{wt} \% \mathrm{Mg})$ synthesized via combustion method at a) $\left.380^{\circ} \mathrm{C} \mathrm{b)} 480^{\circ} \mathrm{C} \mathrm{c}\right) 580^{\circ} \mathrm{C}$.

According to the figure 2 (a) and (b), the XRD pattern of the samples synthesized at temperatures below $580^{\circ} \mathrm{C}$ show several additional peaks due to existence of crystalline phases other than LTB which could be produced by incomplete reactions between the starting materials. Therefore, the synthesized sample at temperature $580^{\circ} \mathrm{C}$ (LTB-NPs) was selected for further analysis. XRD peaks are compared with the original LTB card using the International Center for Diffraction Data (ICDD) PDF card (ICDD 40-0505 (LTB)) for phase identification. XRD pattern of LTB-NPs confirmed tetragonal crystalline phase of the sample and the sharpens of the peaks in figure 
2c confirms the good crystallinity. Williamson-Hall's formula determines the crystallite size of the NPs through the below relation [39]:

$$
\beta \cos \theta=(0.89 \lambda) / d+4 \varepsilon \sin \theta
$$

where $\lambda, \beta, \theta, \varepsilon$ and $\mathrm{d}$ respectively ascertain the wavelength of $\mathrm{Cu} \mathrm{K} \alpha$ radiation $(1.5406 \AA)$, full-width at half maximum of the diffraction peak (FWHM), Bragg angle, strain and the mean size of particles [39]. Figure 3 shows the variation of $\beta \cos \theta$ with $4 \sin \theta$. According to the linear fit of the data, the crystallite size is determined from the y-intercept using Eq. 1. The average size of LTB-NPs was obtained as $\sim 47 \mathrm{~nm}$.

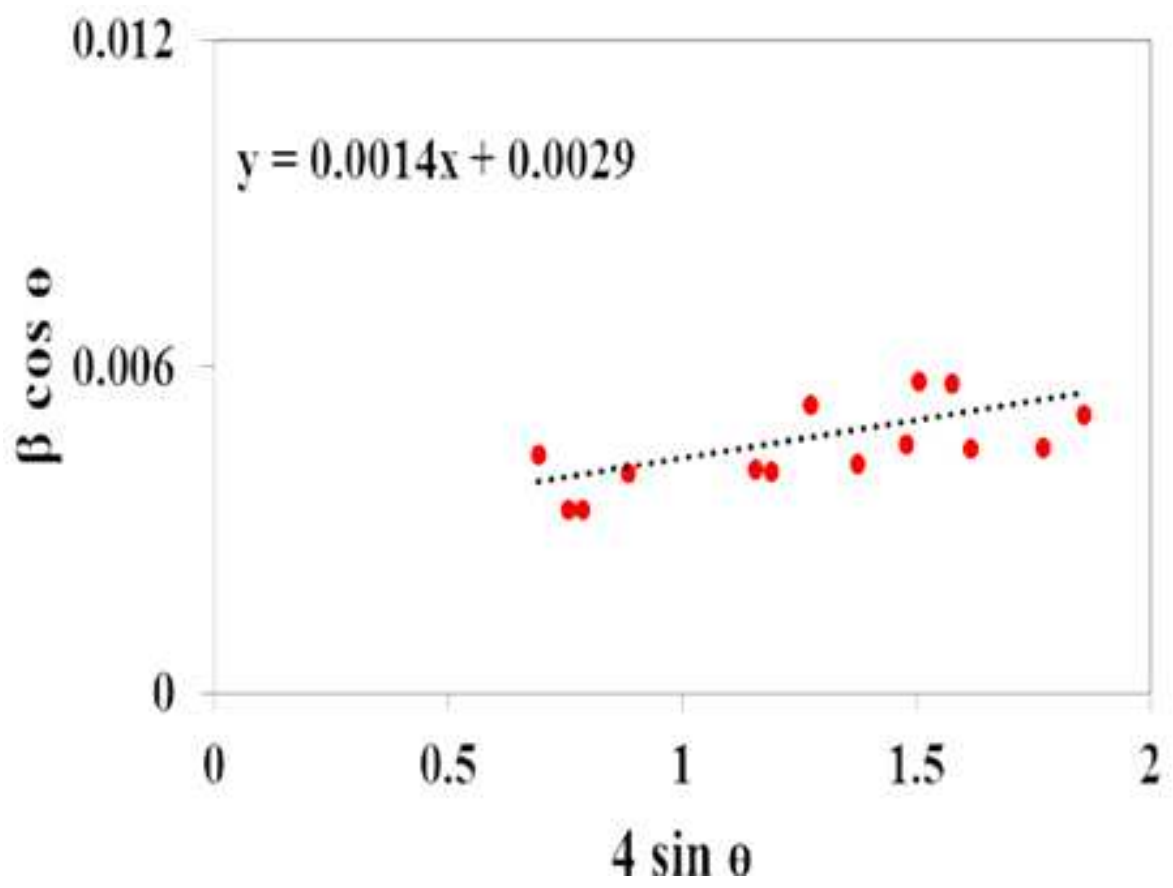

Fig.3. Williamson-Hall's plot of LTB: $\mathrm{Cu}, \mathrm{Mg}(0.02 \mathrm{wt} \% \mathrm{Cu}$ and $0.5 \mathrm{wt} \% \mathrm{Mg})$ NPs synthesized via combustion method.

The absorbance spectrum of LTB-NPs is depicted in Figure 4 with the main peak around $290 \mathrm{~nm}$. The inset graph shows the Tauc plot which can be used to estimate the band gap through the below equation [40]:

$$
\alpha \mathrm{h} v=\mathrm{A}(\mathrm{h} v-\mathrm{Eg})^{n}
$$

Where $\mathrm{A}$ is a constant, $\mathrm{h} v$ is photon energy, $\alpha$ is the absorption coefficient, $\mathrm{E}_{\mathrm{g}}$ is the optical band gap, $\mathrm{n}=1 / 2$ for the direct transition and $n=2$ for indirect transition. The linear fit of $(\alpha h v)^{2} v s$. $h v$ allows calculating the band gap of the LTP-NPs. The indirect optical band gap of $\sim 3.7 \mathrm{eV}$ was measured for the synthesized NPs from the UV 
visible absorption spectra by using the Tauc plot (inset of the figure) and identifying the intercept at abscissa, which is in accordance with the previous work [41].

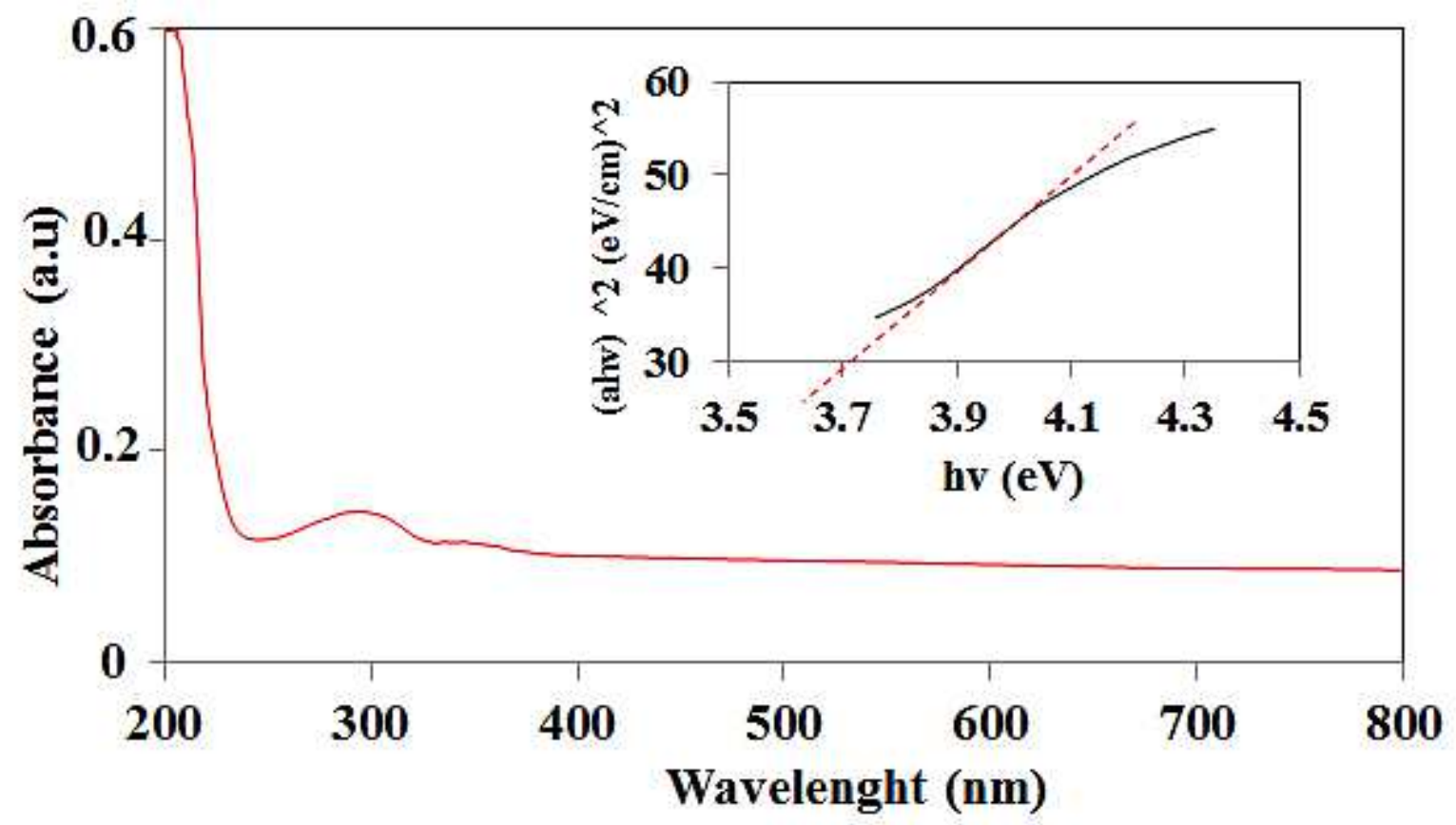

Fig. 4. Absorption spectra LTB: $\mathrm{Cu}, \mathrm{Mg}(0.02 \mathrm{wt} \% \mathrm{Cu}$ and $0.5 \mathrm{wt} \% \mathrm{Mg}) \mathrm{NPs}$. The inset shows the Tauc plot. The main purpose of this study is to investigate the TL properties of LTB crystals doped with $\mathrm{Cu}$ and $\mathrm{Mg}$ which have the highest sensitivity to gamma radiation. The sample synthesized at temperature of $380^{\circ} \mathrm{C}$ did not show any sensitivity to gamma rays and the sample synthesized at $580^{\circ} \mathrm{C}$ was 2 times more sensitive to gamma rays than that produced at $480^{\circ} \mathrm{C}$. Therefore, after examining the sensitivity of the 3 samples mentioned above, nanopowder samples (synthesized at $580^{\circ} \mathrm{C}$ ) with the highest sensitivity to gamma rays and high crystalline grade compared to the other two samples were selected for TL dosimetry of gamma rays. However, the increased sensitivity to gamma rays in nanopowders synthesized at higher temperatures can be attributed to good replacement of impurities in the crystal structure.

The effect of $\mathrm{Cu}$ and $\mathrm{Mg}$ impurities on the TL sensitivity of LTB-NPs is also studied. At first, the amount of copper was kept constant $(0.02 \mathrm{wt} \%)$ then $\mathrm{Mg}$ was used with amounts of $0.01,0.03,0.05,0.1,0.5$ and $1 \mathrm{wt} \%$. Subsequently, $\mathrm{Mg}$ was taken constant $(0.5 \mathrm{wt} \%)$ and various concentration of $\mathrm{Cu}(0.01,0.03,0.05,0.1,0.5$ and 1 wt $\%$ ) was added to the mixture. TL features of the produced LTB:Cu,Mg NPs were investigated following irradiation with the ${ }^{60} \mathrm{Co}$ gamma ray at room temperature. Figure 5 illustrates the effect of $\mathrm{Cu}$ and $\mathrm{Mg}$ impurities on the TL response of LTB nanopowders. 
As is showed in figure 5, $0.02 \mathrm{wt} \%$ of $\mathrm{Cu}$ and $0.5 \mathrm{wt} \%$ of $\mathrm{Mg}$ are the optimal impurity concentrations in LTB-

NPs to achieve the highest TL sensitivity.

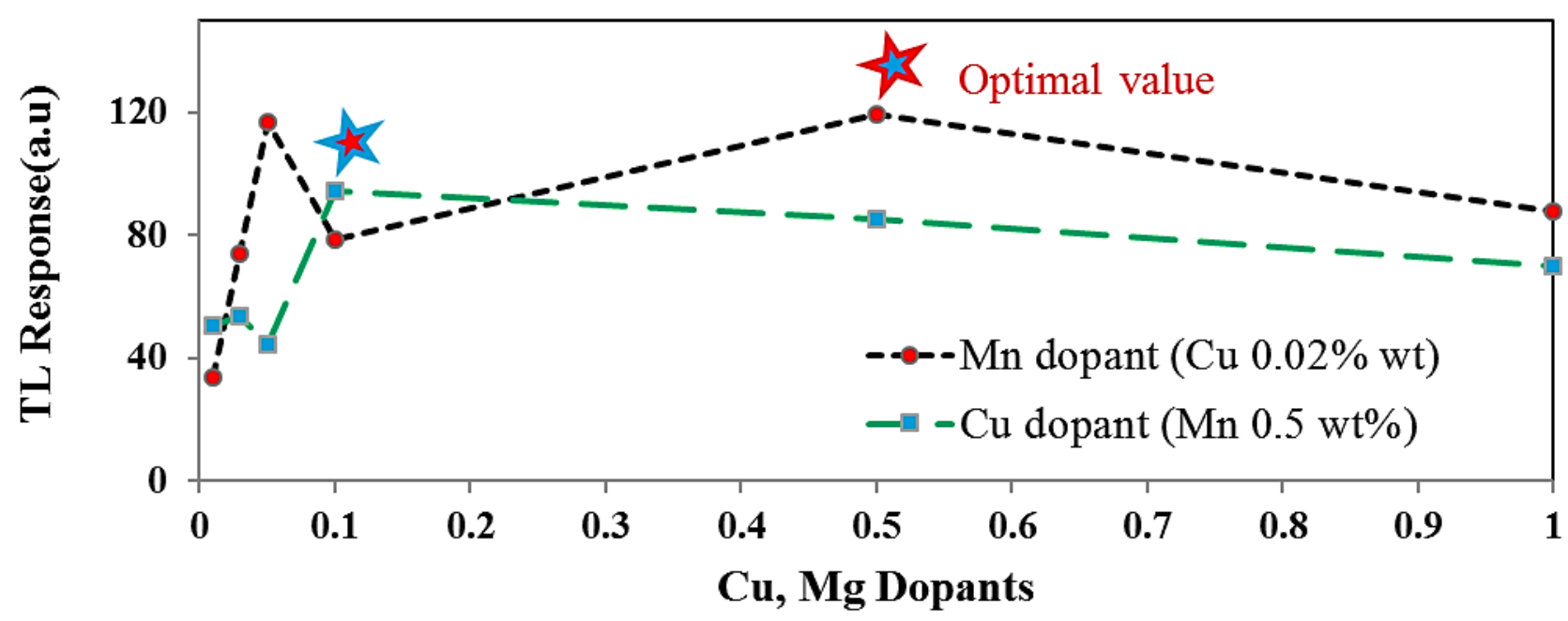

In this study, to investigate the TL glow curve, the general order kinetics model, which is widely used to describe the TL peaks, was used. A computerized glow curve deconvolution (CGCD) technique was applied to estimate the trapping parameters of the overlapping peaks based on this model. In this method, a glow curve deconvolution function is exploited in terms of the intensity and the temperature of the peak maximum ( $\mathrm{Im}, \mathrm{Tm})$, kinetic order (b) and activation energy (E) where the equation of TL intensity is as follows [42]

$$
I(T)=I_{m} b^{\frac{b}{b-1}} \exp \left(\frac{E}{k T} \cdot \frac{T-T_{m}}{T_{m}}\right) \times\left[(b-1)(1-\Delta) \frac{T^{2}}{T_{m}^{2}} \cdot \exp \left(\frac{E}{k T} \cdot \frac{T-T_{m}}{T_{m}}\right)+Z_{m}\right]^{\frac{-b}{b-1}}
$$

Where $\mathrm{k}$ and $\mathrm{T}$ are the Boltzmann's constant and temperature respectively and $\Delta=2 k T / E$

$$
\begin{aligned}
& \Delta_{m}=2 k T_{m} / E \\
& Z_{m}=1+(b-1) \Delta_{m}
\end{aligned}
$$

Figure 6 and Table 1 show the component glow peaks and the TL kinetic parameters of the LTB: $\mathrm{Cu}, \mathrm{Mg}(0.02$ wt $\% \mathrm{Cu}$ and $0.5 \mathrm{wt} \% \mathrm{Mg}$ ) NPs irradiated with ${ }^{60} \mathrm{Co}$ gamma rays.

A relatively low figure of merit (FOM) of $1 \%$ indicates good agreement of experimental and theoretical peaks based on the general order of the kinetic model [43]. 


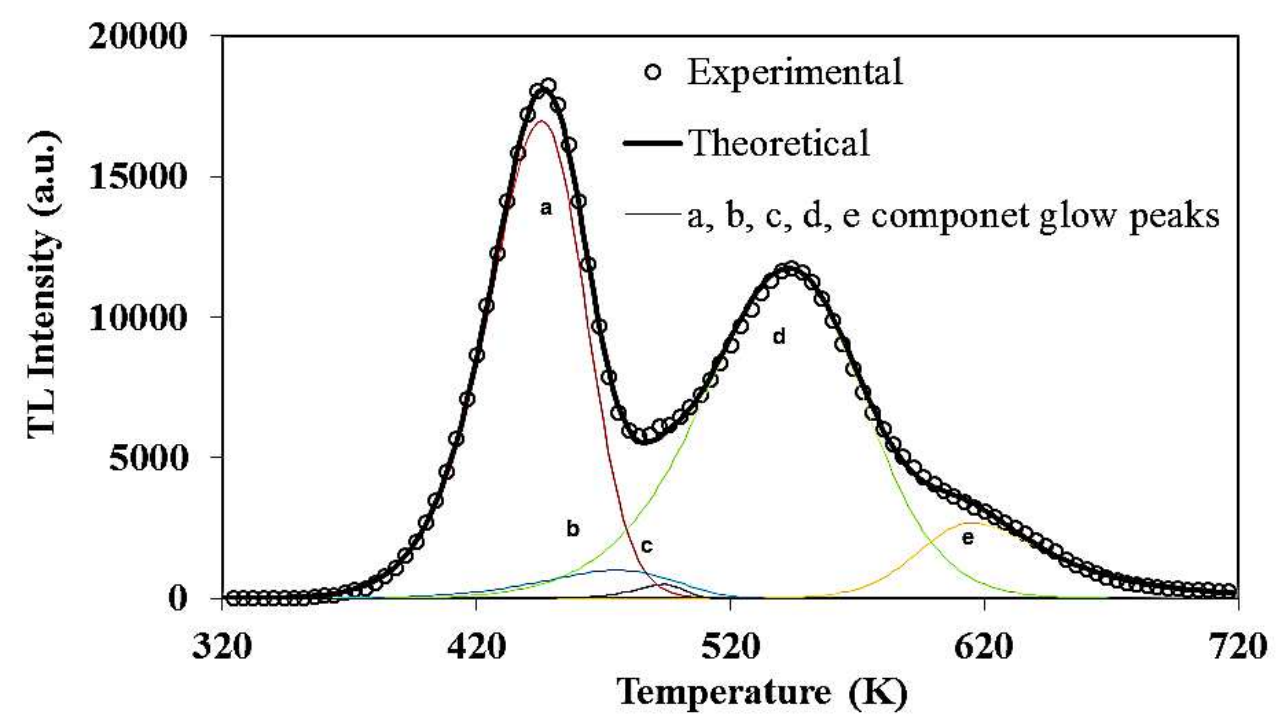

Fig.6. Experimental and deconvolved glow curve of LTB: $\mathrm{Cu}, \mathrm{Mg}(0.02 \mathrm{wt} \% \mathrm{Cu}$ and $0.5 \mathrm{wt} \% \mathrm{Mg}) \mathrm{NPs}$ for 30000 Gy gamma irradiation with ${ }^{60} \mathrm{Co}$ source.

Table 1: TL trapping parameters of component glow peaks of LTB: $\mathrm{Cu}, \mathrm{Mg}(0.02 \mathrm{wt} \% \mathrm{Cu}$ and $0.5 \mathrm{wt} \% \mathrm{Mg})$ NPs.

\begin{tabular}{|c|c|c|c|c|}
\hline \multirow[t]{2}{*}{ peaks } & \multicolumn{4}{|c|}{ LTB: $\mathrm{Cu}, \mathrm{Mg}(0.02 \%$ wt $\mathrm{Cu}$ and $0.5 \%$ wt $\mathrm{Mg}) \mathrm{NPs}$} \\
\hline & $I_{m}(\mathrm{a} . \mathrm{u})$ & $\mathrm{T}_{\mathrm{m}}(\mathrm{K})$ & $\mathrm{E}(\mathrm{eV})$ & $\mathrm{b}$ \\
\hline a & 17000 & 445 & 0.97 & 1.2 \\
\hline $\mathrm{b}$ & 1000 & 473 & 0.69 & 1 \\
\hline $\mathrm{c}$ & 502 & 493 & 1.67 & 1.2 \\
\hline d & 11722 & 541 & 0.91 & 1.3 \\
\hline e & 2690 & 618 & 1.68 & 2 \\
\hline
\end{tabular}

As is observed in figure 6, the glow curve contains five overlapping glow peaks between 445 and $618 \mathrm{~K}$. The glow curve of the sample has two major peaks around 445 and $541 \mathrm{~K}$ and 3 small satellite peaks around 473,493 and $618 \mathrm{~K}$. The TL properties of materials are highly dependent on the natural defects and the impurities inserted 
in the host lattice [44]. Based on the previous reports, $\mathrm{Cu}^{+}$ions not only substitute for $\mathrm{Li}^{+}$ions but also situate at the interstitial sites and act as charge compensator in the LTB structure [45]. After irradiation, $\mathrm{Cu}^{+}$ions act as recombination or trapping centers and become $\mathrm{Cu}^{2+}$ active or $\mathrm{Cu}_{\mathrm{A}}^{0}$ and $\mathrm{Cu}_{\mathrm{B}}^{0}$ form respectively $[45,46]$. The glow peak observed near $445 \mathrm{~K}$ might be attributed to the decay process of $\mathrm{Cu}$ during heating. It is worth noting that the relative intensity of TL is changed with increasing Mg concentration. Some of $\mathrm{Li}$ atoms are in the tetrahedral lacunas which have little aberrance, and the others are in the oxygenic octahedral lacunas which have much aberrance [47]. When the dopant atoms with a large radius come into the LTB structure, the lattice will be distorted. The length of the $\mathrm{B}-\mathrm{O}$ bond in some complexes $\left(\mathrm{BO}_{3}\right)$ possibly decreases. The lacunas which contain the dopant atoms are not tetrahedrons or octahedrons any longer, the number of oxygenic atoms that bond with the dopant atom can reach 7 or 8 , and the bond distances have a large range. When the $\mathrm{Mg}$ dopant atoms come into the LTB structure, the complexes $\mathrm{MgO}$ and $\mathrm{B}_{2} \mathrm{O}_{3}$ are generated; especially the latter. This has some relations with the traps corresponding to the TL glow peak in this phosphor [48].

In the following, the TL dose response of NPs under gamma irradiation is investigated. LTB-NPs samples were irradiated in the absorbed dose range of $10 \mathrm{~Gy}$ to $30 \mathrm{KGy}$. Figure 7 shows the dose response of LTB-NPs doped with $\mathrm{Cu}-\mathrm{Mg}$ on a logarithmic basis. The dose response is defined as the functional dependence of the intensity of the measured TL signal upon the adsorbed dose.

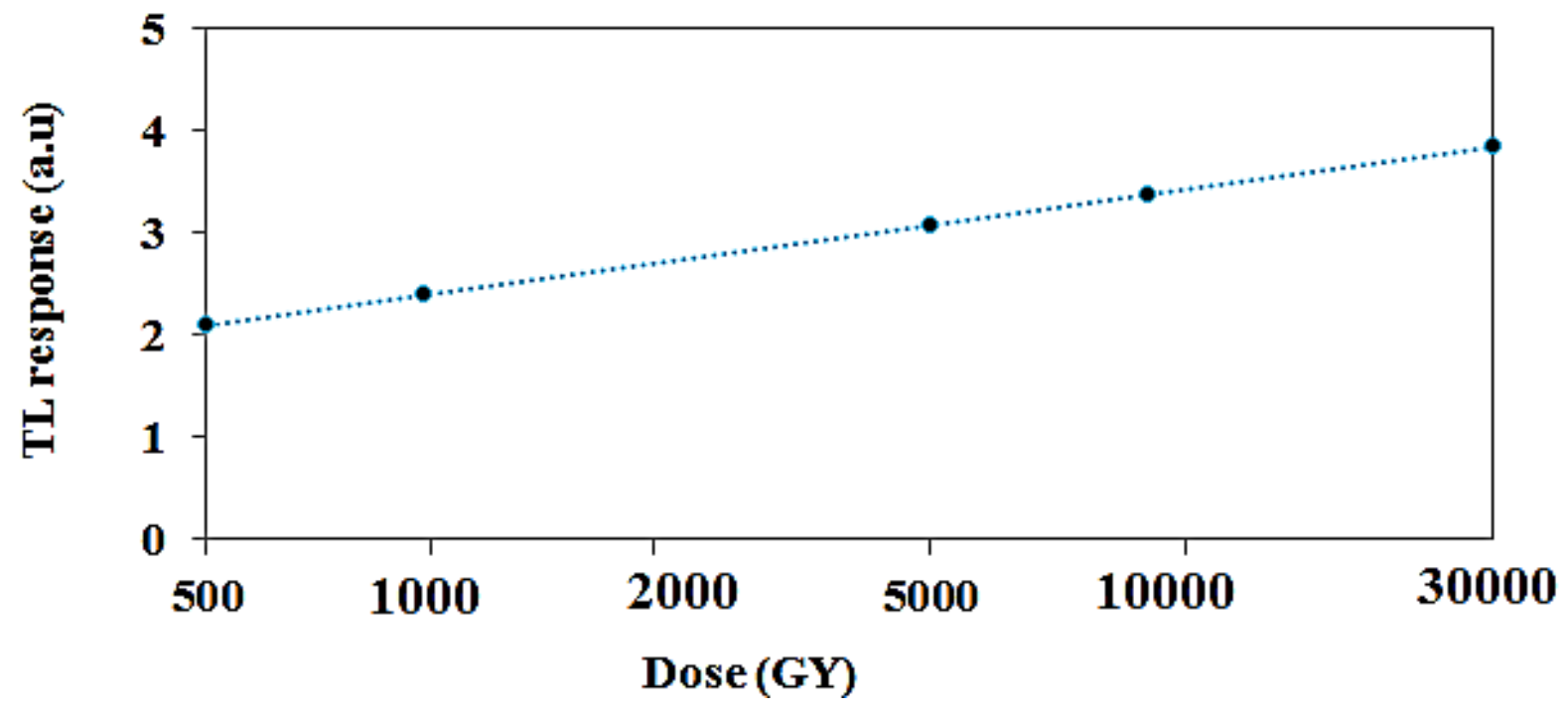

Fig.7.Dose response of LTB: $\mathrm{Cu}, \mathrm{Mg}(0.02 \mathrm{wt} \% \mathrm{Cu}$ and $0.5 \mathrm{wt} \% \mathrm{Mg})$ NPs irradiated with ${ }^{60} \mathrm{Co}$ source (30000 Gy). 
LTB nanoparticles doped with $\mathrm{Cu}-\mathrm{Mg}$ have a linear behaviour in the range of $500 \mathrm{~Gy}$ to $30000 \mathrm{~Gy}$. To determine the fading of LTB-NPs, the nanopowders were firstly irradiated to gamma radiation (30000 Gy) at room temperature and then were kept at dark at room temperature. Afterwards, the TL response was measured at different storage times up to 30 days. Figure 8 shows the fading curve for nanocrystalline doped with $\mathrm{Cu}-\mathrm{Mg}$ impurities. As is evident, the stored TL signal experiences about 10\% fading after one month of storage at room temperature and then remains unchanged.

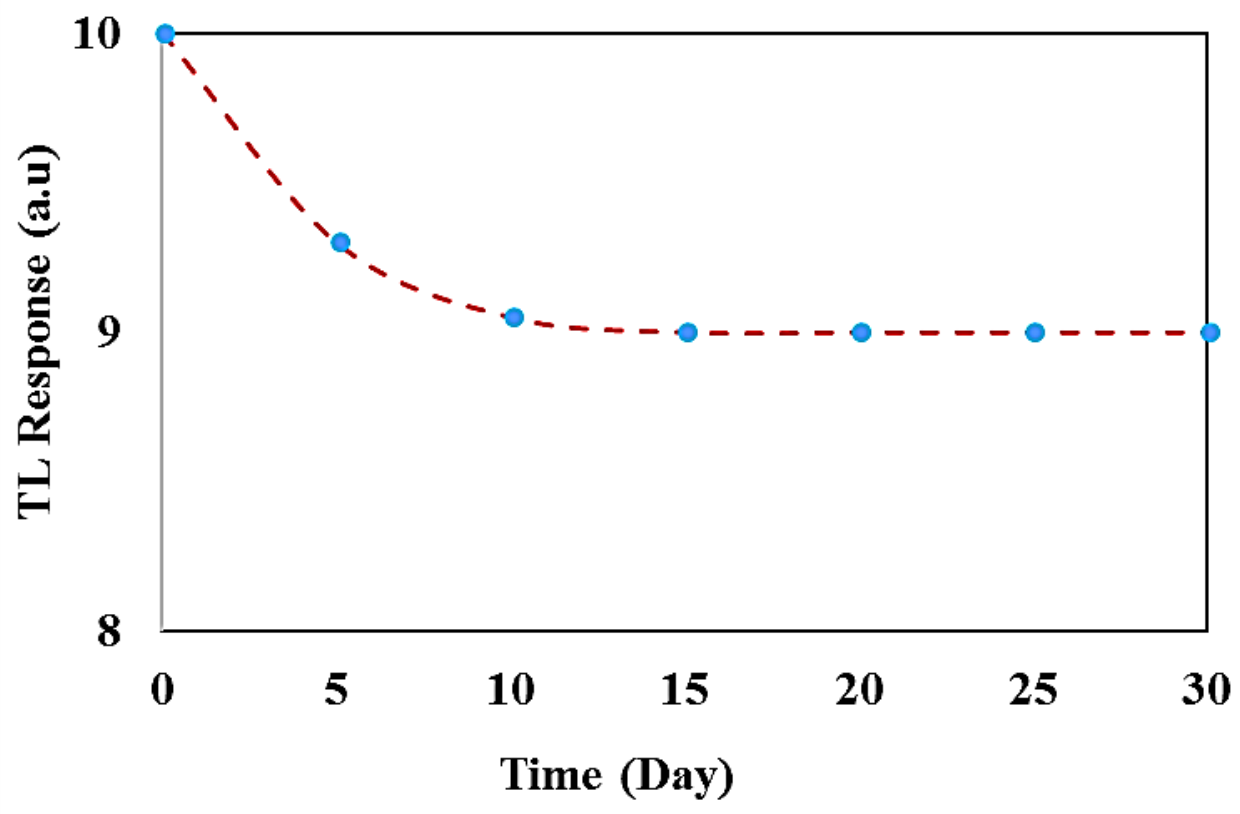

Fig 8. TL response of LTB: $\mathrm{Cu}, \mathrm{Mg}(0.02 \mathrm{wt} \% \mathrm{Cu}$ and $0.5 \mathrm{wt} \% \mathrm{Mg})$ NPs irradiated with ${ }^{60} \mathrm{Co}$ source $(30000$ Gy) after 30 days.

\section{CONCLUSION:}

In this research LTB-NPs co-doped with $\mathrm{Cu}$ and $\mathrm{Mg}$ were synthesized via combustion method. The experimental results show that the nanopowders could be produced at $580{ }^{\circ} \mathrm{C}$ for 1 hour at ambient pressure. Under these conditions, the LTB-NPs with an average size of $\sim 47 \mathrm{~nm}$ and tetragonal phase as well as the optical band gap of $\sim 3.7 \mathrm{eV}$ are produced. The annealed LTB-NPs co-doped by $0.02 \mathrm{wt} \% \mathrm{Cu}$ and $0.5 \mathrm{wt} \% \mathrm{Mg}$ and irradiated with $\gamma$-rays exhibits a TL glow curve including five overlapping peaks. In the present study, the fading characteristic was also examined which is one of the most important TL characteristics. It was found that almost $10 \%$ of the stored TL fades after one month which may be due to the low temperature peak (first peak) of Cu-Mg doped LTB. The TL response of the sample increases linearly with increasing gamma-ray dose between 500 Gy to 30000 Gy. 
Due to the effective atomic number of LTB, which fairly matches the body tissue as well as high sensitivity, the linearity of dose response in a wide range of absorbed dose and low fading, synthesized nanoparticles co-doped with $\mathrm{Cu}$ and $\mathrm{Mg}$ is recommended as a suitable dosimeter for high dose dosimetry.

\section{Acknowledgements:}

The authors acknowledge the financial support of the Research Council of Persian Gulf University and Research Council of the University of Kashan.

\section{Conflict of interest}

The authors declare no com-petting financial interest.

\section{REFERENCES}

[1] S. Numan, P. D. Sahare, A. A. Rupasov (2007) Thermoluminescence of nanocrystalline LiF: Mg, Cu, P. J Lumin 124: 357-364. https://doi.org/10.1016/j.jlumin.2006.04.004

[2] S. Basun, G.F. Imbusch, D.D. Jia, W.M. Yen (2003) The analysis of thermoluminescence Glow Curves. J Lumin 104: 283-94. https://doi.org/10.1016/S0022-2313(03)00082-6

[3] J. Azorin (1986) Determination of thermoluminescence parameters from Glow Curves. Nucl. Tracks 11:159-166. https://doi.org/10.1016/1359-0189(86)90007-5

[4] A. J. J. Boss (2017) Thrmoluminescence as a research tool to investigate Luminescence. Mechanism. Materials 10:1-22. https://doi.org/10.3390/ma10121357

[5] T. Babita, N.S. Rawat, D. G. Desai, S. G. Singah, M. Tygi, P. Ratna, S. C. Gadkari, M.S.Kulkarni (2010) Thermoluminescence Studies on Cu-doped $\mathrm{Li}_{2} \mathrm{~B}_{4} \mathrm{O}_{7} \quad$ Single Crystals. J Lumin 130:2076-2083. https://doi.org/10.1016/j.jlumin.2010.05.030

[6] Mirjana. Prokic (2001) Lithium borate solid TL detectors. Radiat Meas 33:393-396. https://doi.org/10.1016/S1350-4487(01)00039-7

[7] E. Pekpak, A. Yilmaz, G. Ozbayoglu (2010) An overview on preparation and TL characterization of lithium borates for Dosimetric Use. The Open Mineral Processing Journal 3:14-24. https://doi.org/10.2174/1874841401003010014

[8] E. A. Türkler, E. Ekdal, T. Karali, N. Can (2007) Determination of thermoluminescence kinetic parameters of $\mathrm{Li}_{2} \mathrm{~B}_{4} \mathrm{O}_{7}$. Radiat Meas 42:1280-1284. https://doi.org/10.1016/j.radmeas.2007.06.008 
[9] C. Furetta, M. Prokic, R. Salamon, V. Prokic, G. Kitis (2001) Dosimetric characteristics of tissue equivalent thermoluminescent solid TL detectors based on Lithium Borate. Nucl Instrum Methods 456:411-417. https://doi.org/10.1016/S0168-9002(00)00585-4

[10] A Ozdemir, Z Yegingil, Necmettin Nur, Kasim Kurt, T Tuken, Tolga Depci, G Tansug, Volkan Altunal, V Guckan, G Sigircik, Yan Yu, M Karatasli, Y Dolek (2016) Thermoluminescence study of Mn doped lithium tetraborate powder and pellet samples synthesized by solution combustion synthesis. Journal of Luminescence 173:149-158. https://doi.org/10.1016/j.jlumin.2016.01.013

[11] Yanlin Huang, Guitao Zhou, Jie Qin, Donglei Wei, Hyo Jin Seo (2020) $\mathrm{LiBiO}_{2} / \mathrm{Bi}_{2} \mathrm{O}_{3}$ semiconductor heterojunctions with facile preparation and actively optical performances. Powder Technology 362:690-697. https://doi.org/10.1016/j.powtec.2019.12.032

[12] J. J. Thompson, P. L.Ziemer (1973) The Thermoluminescent properties of Lithium Borate activated by Silver. Health Physic Pergmon Press 25:435-441. https://doi.org/10.1097/00004032-197310000-00009

[13] Takenaga M, Yamamoto O, Yamashita T (1983) A new phosphor $\mathrm{Li}_{2} \mathrm{~B}_{4} \mathrm{O}_{7}$ : $\mathrm{Cu}$ for TLD. Health Physics 44:387393. https://doi.org/10.1097/00004032-198304000-00009

[14] M. Takenaga, O. Yamamoto, T. Yamashita (1980) Preparation and characteristics of $\mathrm{Li}_{2} \mathrm{~B}_{4} \mathrm{O}_{7}$ : $\mathrm{Cu}$ phosphor. Nucl.Instr.Meth 175:77-78. https://doi.org/10.1016/0029-554X(80)90259-1

[15] J. K. Srivastava, S. J. Supe (1989) the thermoluminescence characterization of $\mathrm{Li}_{2} \mathrm{~B}_{4} \mathrm{O}_{7}$ Doped with Cu. J. Physic 22:1537-1543. https://doi.org/10.1088/0022-3727/22/10/020

[16] Z. Xiong, Q. Tang, C. Zhang, Investigation of thermoluminescence in $\mathrm{Li}_{2} \mathrm{~B}_{4} \mathrm{O}_{7}$ phosphor doped with $\mathrm{Cu}, \mathrm{Ag}$ and Mg, Sci China Ser G:Astronomy. 50 (2007) 311-320. https://doi.org/10.1007/s11433-007-0020-3

[17] N. Can, T. Karali, P. D. Townsend, F. Yildiz (2006) TL and EPR studies of Cu, Ag and P doped $\mathrm{Li}_{2} \mathrm{~B}_{4} \mathrm{O}_{7}$ phosphor. J. Phys.D 39:2038-2043. https://doi.org/10.1088/0022-3727/39/10/009

[18] A Ozdemir, GS Polymeris, E Şahiner, E Aşlar, V Guckan, V Altunal, N Meriç, Z Yegingil (2019) Evaluation of thermoluminescence trapping parameters in $\mathrm{Li}_{2} \mathrm{~B}_{4} \mathrm{O}_{7}$ co-doped with $\mathrm{Ag}^{+}$and $\mathrm{Gd}^{3+}$ using various experimental techniques Nuclear Instruments and Methods in Physics Research Section B: Beam Interactions with Materials and Atoms 461:70-76. https://doi.org/10.1016/j.nimb.2019.09.021 
[19] Mohsen. Mehrabi, Mostafa. Zahedifar, Zohreh. Saeidi, Rouhollah. Gheisari, Soheila. Hasanloo(2021) Effect of using ultrasonic waves in synthesis on the size, shape and luminescence properties of $\mathrm{NaCl}: \mathrm{Ce}^{3+}$ crystals for clinical dosimeter application. Materials Chemistry and Physics 263:124374-80. https://doi.org/10.1016/j.matchemphys.2021.124374

[20] M. A. Vallejo, M. A. Sosa, E. Rivera, J. C. Azorín, J. Bernal, R. Navarro, E. K. Encarnación, L. A. Díaz-Torres (2016) Effect of crystal size and Ag concentration on the thermoluminscent response of pure and Ag-doped LiF Cubes. World Scientific Publishing Company 11:1650041-1650049. https://doi.org/10.1142/S1793292016500417

[21] N. Salah, N. D. Alharbi, M. A. Enani (2014) Luminescence properties of pure and doped $\mathrm{CaSO}_{4}$ nanorods irradiated by 15 Mev e-beam Nucl Instrum Methods B 319:107-111. https://doi.org/10.1016/j.nimb.2013.11.012

[22] M. Zahedifar, M. Mehrabi, M. Modares, S. Harooni (2012) Thermoluminescence properties of BeO:Mg nanoparticles produced by Sol-Gel Method. Journal of Nanostructures 1:199-203. https://doi.org/10.7508/jns.2011.03.003

[23] N. Salah, S. S. Habib, Z. H. Khan, S. P. Lochab, The nanoparticles of $\mathrm{BaSO}_{4}:$ Eu as detectors for high doses of different Ionizing Radiations. (2010) Atoms for Peace -An International Journal 3:84-92. https://doi.org/10.1504/AFP.2010.031494

[24] N. Salah, S. S. Habib, Z. H. Khan, S. Al-Hamedi, S. P. Lochab (2009) Nanoparticle of BaSO 4 :Eu for Heavy-dose Measurements. J Lumin 129:192-196. https://doi.org/10.1016/j.jlumin.2008.09.012

[25] N. Y. Abdou, M. M. Farag, W. M. Abd-Allah (2020) Thermoluminescent properties of nano-magnesium phosphate ceramic for radiation dosimetry. Eur. Phys. J. Plus 135:317;1-12 https://doi.org/10.1140/epjp/s13360-02000310-1

[26] M. Zahedifar, M. Mehrabi (2010) Thermoluminescence and photoluminescence of cerium doped $\mathrm{CaSO}_{4}$ nanosheets. Nucl Instrum Methods 268:3517-3522. https://doi.org/10.1016/j.nimb.2010.08.014

[27] A. I. Surdo, V. A. Pustovarov, V. S. Kortov, A. S. Kishka, E. I. Zinin (2005) Luminescence in anion-defective $\alpha-$ $\mathrm{Al}_{2} \mathrm{O}_{3}$ crystals over the nano- micro- and Millisecond Intervals. Nucl Instrum Methods A 543:234-238. https://doi.org/10.1016/j.nima.2005.01.189 
[28] A. Yahyaabadi, F. Torkzadeh, D. Rezaei-Ochbelagh (2018) Characteristic of thermoluminescence LiF:Mg, Cu, Ag NanoPhosphor. Radiat Prot Dosim 82:266-272. https://doi.org/10.1093/rpd/ncy062

[29] M. Zahedifar, E. Sadeghi, M. M. Shanei, A. Sazgarnia, M. Mehrabi (2016) Afterglow properties of CaF $2: T m$ nanoparticles and its potential application in photodynamic therapy. $\mathrm{J}$ Lumin 171:254-258. https://doi.org/10.1016/j.jlumin.2015.11.043

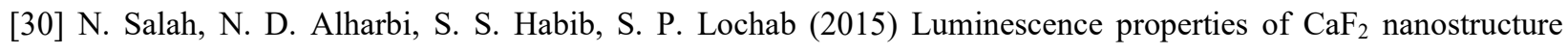
activated by Different Elements. Jornal of Nanomaterials 2015:136402-136408. https://doi.org/10.1155/2015/136402

[31] Effect of size variation and gamma irradiation on thermoluminescence and photoluminescence characteristics of $\mathrm{CaSO}_{4}$ : Eu micro- and nanophosphors, Nandkumar T. Mandlik Ph.D, P. D. Sahare Ph.D, S. D. Dhole Ph.D (2020) Applied Radiation and Isotope 159:109080-88. https://doi.org/10.1016/j.apradiso.2020.109080

[32] M. Mehrabi, M. Zahedifar, Z. Saeidi-Sogh, A. Ramazani-Moghaddam-Arani, E. Sadeghi, S. Harooni (2017) Thermolinescence and photoluminescence properties of $\mathrm{Nacl}: \mathrm{Mn}, \mathrm{NaCl}: \mathrm{Cu}$ nano-particle using co-precipitation and Sono-Chemistry Methods. Nucl Instrum Methods A 846:87-93. https://doi.org/10.1016/j.nima.2016.10.001

[33] S. Delice, M. Isik, N. M. Gasanly (2019) Low temperature thermoluminescence behaviour of $\mathrm{Y}_{2} \mathrm{O}_{3} \mathrm{Nanoparticles.}$ J Rare Earth 37:19-23. https://doi.org/10.1016/j.jre.2018.06.005

[34] B. Samariha, K. R. Saraee (2018) Effect of annealing on the thermoluminescence characteristics of Dy and Tb doped $\mathrm{SrSO}_{4}$ nanophosphor under Gamma Excitation. J Lumin 17:31773-31778. https://doi.org/10.1016/j.jlumin.2018.02.057

[35] M. Isik, N. M. Gasanly (2018) Trap characterization by photo-transferred thermoluminescence in $\mathrm{MgO}$ nanoparticles. Phys B: Condensed Matter 537:301-305. https://doi.org/10.1016/j.physb.2018.02.041

[36] K. R. Nagabhushana, D. Prakash, F. Singh, S. H. Tatumi, R. R. Rocca, S. Watanabe (2018) Comparative studies on thermoluminescence glow curves of calcium oxide nanophosphor irradiated with various Ionizing Radiations. J. Alloys Compd 735:1949-54. https://doi.org/10.1016/j.jallcom.2017.11.148

[37] M. Rahimi, M. Zahedifar, E. Sadeghi (2018) Synthesis, optical properties and thermoluminescence dosimetry features of manganese doped $\mathrm{Li}_{2} \mathrm{~B}_{4} \mathrm{O}_{7}$ Nanoparticles. Radiat Prot Dosim 181:1-8. https://doi.org/10.1093/rpd/ncy035 
[38] L. Singh, V. Chopra, S. P. Lochab (2011) Synthesis and characterization of thermoluminescence $\mathrm{Li}_{2} \mathrm{~B}_{4} \mathrm{O}_{7}$ Nanophosphor. J Lumin 131:1177-1183. https://doi.org/10.1016/j.jlumin.2011.02.035

[39] G. K. Williamson, W. H. Hall, X-ray line broadening from filealuminium and wolfram, Acta Metall. 1 (1953): 22-31. https://doi.org/10.1016/0001-6160(53)90006-6

[40] J. Tauc (1968) Optical properties and electronic structure of amorphous Ge and si. Mater Res Bull 3:37-46. https://doi.org/10.1016/0025-5408(68)90023-8

[41] R. Mohandoss, S. Dhanuskodi, B. Renganathan, D. Sastikumar (2013) Gas sensing property of lithium tetraborate clad modified fiber optic sensor. Current Applied Physics 13:957-963. https://doi.org/10.1016/j.cap.2013.01.038

[42] G. Kitis, J. M. Gomez-Ros, J. W. N. Tuyn (1998) Thermoluminescence glow-curvedeconvolution functions for first, second and general order of kinetics. J. Phys. D Appl. Phys 31:2636. https://doi.org/10.1016/S01689002(99)00876-1

[43] H. G. Balian, N. W. Eddy (1977) Figure-of-merit (FOM), an improved criterion over the normalized chi-squared test for assessing goodness of-fit of gamma-ray spectra peaks. Nucl. Instrum. Methods 145:389-393. https://doi.org/10.1016/0029-554X(77)90437-2

[44] S. W. McKeever, M. Moscovitch, P. D. Townsend, Thermoluminescence Dosimetry Materials: Properties and Uses, Nuclear Technologies Publishing, 1995; Ashford, UK. https://doi.org/10.1088/0952-4746/16/4/018

[45] A. T. Brant, D. A. Buchanan, J. W. McClory, P. A. Dowben, V. T. Adamiv, Y. V. Burak, L.E.Halliburton (2013) Identification of defects responsible for thermoluminescence in $\mathrm{Cu}$-doped lithium tetraborate $\left(\mathrm{Li}_{2} \mathrm{~B}_{4} \mathrm{O}_{7}\right)$. crystals, $\mathrm{J}$. Lumin 139:125-131. https://doi.org/10.1016/j.jlumin.2013.02.023

[46] G. Corradi, V. Nagirnyi, A. Kotlov, A. Watterich, M. Kirm, K. Polgár, A. Hofstaetter, M. Meyer (2007) Investigation of $\mathrm{Cu}$-doped $\mathrm{Li} 2 \mathrm{~B} 4 \mathrm{O} 7$ single crystals by electron paramagnetic resonance and time-resolved optical spectroscopy. J. Phys. Condens. Matter 20:25216. https://doi.org/10.1088/0953-8984/20/02/025216

[47] M. M. Islam, V. V. Maslyuk, T. Bredow, C. Minot (2005) Structural and electronic properties of $\mathrm{Li}_{2} \mathrm{~B}_{4} \mathrm{O}_{7}$. J Phys Chem B 109:13597-13604. https://doi.org/10.1021/jp044715q 
[48] Y. Ono, M. Nakaya, T. Sugawara, N. Watanabe, H. Siraishi, R. Komatsu, TuyoshiKajitani (2001) Structural study of $\mathrm{LiKB}_{4} \mathrm{O}_{7}$ and $\mathrm{LiRbB}_{4} \mathrm{O}_{7}$ : New nonlinear optical crystals. J Cryst Growth 229:472-476. https://doi.org/10.1016/S0022-0248(01)01210-6 